\title{
Isolation and Identification of Bacteria Producing Biogum as a Potential Manufacturer of Halal Hydrocolloid Material
}

\author{
E Q Ainy ${ }^{1}, \mathrm{R}$ Afifah ${ }^{2}$ \\ UIN Sunan Kalijaga, Jl. Marsda Adisucipto No. 1 Yogyakarta, Indonesia 55281 \\ \{erny.ainy@uin-suka.ac.id ${ }^{1}$.,rifaatul.afifah@uin-suka.ac.id²\}
}

\begin{abstract}
Biogum is an additional materials that has been applied widely in industries. It is a critical point in assuring of halal products because of its original material. Microbial biogum has been applied widely in industries. Xanthomonas campestris, a phytopathogenic bacteria in Brassicaceae has been found as a potential manufacturer of microbial gum. However, the high cost of glucose utilization in biogum fermentation has stimulated the using of organic waste such as cassava baggase as an alternative for carbon source. The aims of this study are to reveal the local isolates' ability in biogum production using cassava baggase and to identify the potential isolates by profile matching method. Pathogenic bacteria were isolated from Brassica's leaf with black rot symptom that inoculated in GYCA (Glukosa Yeast $\mathrm{CaCO}_{3}$ Agar). The capability of isolates in biogum production was tested by fermentation using cassava baggase. There were four isolates of bacteria producing biogum from cassava baggase they were SH2, SHA2, SHB1 that identified as Pseudomonas, and SHD5 was identified as Erwinia.
\end{abstract}

Keywords: Bacteria, Biogum, Cassava Baggase

\section{Introduction}

Microbial gum, a popular biogum, is a microbial exopolysaccharide with high molecular weight, environment-friendly, and valuable natural polymers, having applications in diverse areas such as the food industry, pharmaceutical industry, cement systems, and cosmetics industries [1]. It acts as a thickening, suspending, binding, emulsifying, stabilizing and viscosifying agent. It has important commercial applications in the cement systems. The biopolymer is synthesized by the fermentation process mainly by Xanthomonas campestris [2]. Xanthomonas campestris pv. campestris is a gram-negative bacterium that is a pathogen of cruciferous plants causing black rot disease affecting economically important crops as wells as ornamentals and weeds. This vascular disease, which may ultimately lead to plant death, causes typical V-shaped lesions on the leaf margins, following hydathodes infection darkening of the veins. Xcr causes leaf spot disease on both Brassicaceae and Solanaceae hosts and is characterized by small dark spots that develop to brown lesions often surrounded by chlorotic halos [3]. However, Xanthomonascampestris is safe to be applied in biogum production because it is safe for humans. It only attacks plants, has no endospores and produces biogum that is stable at a wide range of temperatures and $\mathrm{pH}$. United States of Food and Drug Administration (FDA) has also approved the application of biogum of $X$. campestris [4].

Research on isolates and biogum produced by Xanthomonas has not been carried out in Indonesia widely because it is usually only about its pathogenicity in plants. The existence of these problems encourages the use of existing characters in Xanthomonas as a reference for the exploration of biogum-producing microbes from mustard greens hoping that the isolates obtained are Xanthomonas sp.

Microbial gum is produced by fermentation using different sources of carbon or nitrogen [5]. Biogum fermentation using a glucose substrate as a carbon source is more expensive and it represents $30 \%$ of production cost [6]. The problems can be solved by using alternative carbon sources derived from by-products or agro-industrial organic waste [7], one of them is cassava baggase.

Cassava baggase is usually used for animal feed or just thrown away in the environment that can lead to serious air pollution problems causing the appearance of spoilage microbes, thus giving off an unpleasant odor. However, its nutrient content is about $43.1 \% \mathrm{db}$ (dry basis) of starch and $47.1 \% \mathrm{db}$ of dietary fiber [8]. The high carbohydrate content causes cassava baggase having potential as a carbon source for biogum 
fermentation. The aim of this research is to obtain local bacteria producing biogum using alternative fermentation media from cassava baggase.

\section{Method}

\section{Isolation and Purification of Bacteria Producing Biogum}

Green mustard leaves with symptoms of black rot were cut aseptically. Pieces of leaves were washed with sterile distilled water for 5 minutes, then soaked in Clorox 1\% for 1 minute [9]. The leaf pieces were then placed on a plate of GYCA media (in $1 \mathrm{~L}$ containing 10 grams of glucose; 5 grams of yeast extract; 30 grams of $\mathrm{CaCO} 3 ; 20$ grams of agar) and incubated for 4 days at $30^{\circ} \mathrm{C}$. Isolates with colony characteristics similar to Xanthomonas campestris namely, yellow and orange, circular in shape, smooth and shiny colony surface and mucoid or viscid, and stretchy properties in tactile tests were selected and purified. The pure cultures were then stored using YMA media (in $1 \mathrm{~L}$ containing 10 grams of glucose; 3 grams of yeast extract; 5 grams of peptone; 3 grams of malt extract; 20 grams of agar).

\section{Screening Isolates Producing Biogum with Alternative Carbon Sources}

24-hour-old bacterial isolates were inoculated on YMB media (in $1 \mathrm{~L}$ containing 10 grams of glucose; 3 grams of yeast extract; 5 grams of peptone; 3 grams of malt extract) and media with alternative carbon sources in the form of cassava baggase (YPGCb: in $1 \mathrm{~L}$ containing 3 grams yeast extract; 5 -gram peptone; $1 \%$ glucose; $0.9 \%$ cassava baggase). Liquid culture of $2 \%(\mathrm{v} / \mathrm{v})$ with its optical density (OD) value of 0.5 at a wavelength of $600 \mathrm{~nm}$ was put in $50 \mathrm{~mL}$ of YMB media and incubated in an orbital incubator $(150 \mathrm{rpm})$ at room temperature for 96 hours. The results of fermentation were known by measuring bacterial cell growth (cell dry weight) and biogum production which is carried out at the 0-96 hours [10]. The same way was done for the YPGCb culture with $1 \%$ cassava baggase concentration and $0.9 \%$ glucose.

\section{Characterization and Identification of Selected Isolates Producing Biogum}

The selected isolates that produce biogum using alternative carbon sources were observed for their phenotypic character in the form of the colony and cell morphology, biochemical activity, physiological characteristics and resistance to several antibiotics. The identification was conducted by the profile matching method and adjusted for key characters in Bergey's Manual of Determinative Bacteriology.

\section{Result and Discussion}

There were 10 isolates of pathogenic bacteria that cause black rot disease in green mustard greens in the Kopeng, Magelang, Central Java agricultural area. Based on the ability of isolates to produce biogum using fermentation media YMB and YPGCb (Figure 1), it is known that cell growth (biomass) with biogum production for each isolate varies in each fermentation media. Cell growth and biogum production in YPGCb fermentation media in some isolates tend to be higher than cell growth and biogum production using YMB media.

The highest cell growth was obtained in YPGCb media, namely $3.20 \mathrm{~g} / \mathrm{L}$ by SHA1 isolates, while the highest biogum production was $0.70 \mathrm{~g} / \mathrm{L}$, produced by isolates SH2 and SHA2 in the same media. In the same fermentation media, biogum production from both SH2 and SHA2 isolates was higher than Xc isolates with biogum production of $0.65 \mathrm{~g} / \mathrm{L}$ which had the same level of biogum production with SHB1 isolates. Isolate SHD 5 has a high enough biogum production after isolates Xc and SHB1 in the same fermentation media, which is $0.55 \mathrm{~g} / \mathrm{L}$. 


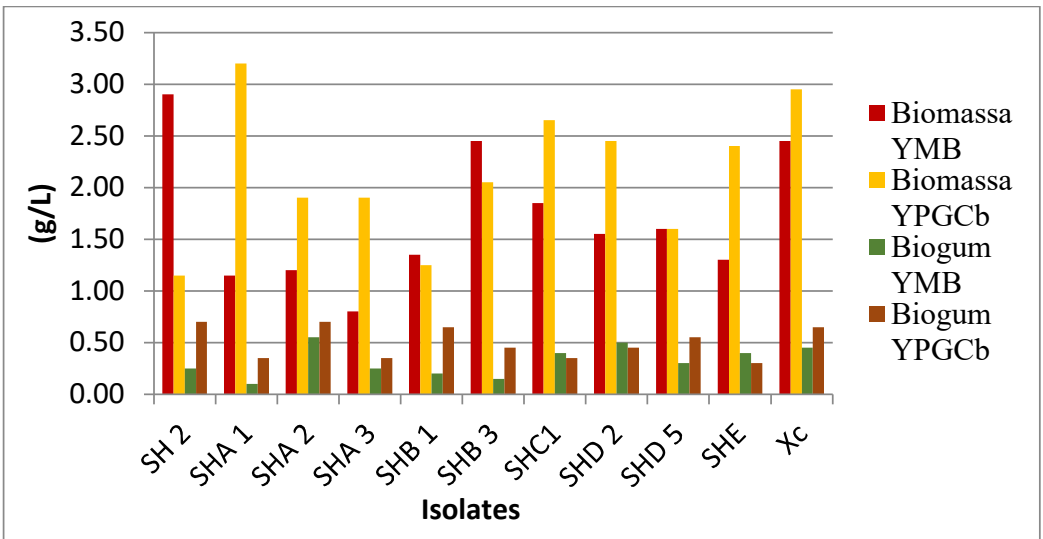

Figure 1. Fermentation results in the form of dry cell weight (biomass) and biogum at the selection stage of the highest biogum-producing isolates using YMB media and YPGCb media

Selection of biogum-producing isolates using fermentation media with YPGCb media obtained 4 selected isolates, they were SH2, SHA2, SHB1, and SHD5. In Figure 2, each of the selected isolates had a yellow, pale yellow and orange colony, glossy wet with an opaque internal structure and had stretchy (mucoid) properties during the tactile test. The cells themselves were rod and Gram-negative. Other phenotypic characters of the four isolates are shown in Table 1.

The results of identification of the genus level by the profile matching method (Table 2) showed that the four selected isolates that we're able to produce biogum using an alternative carbon source did not have the same key character as Xanthomonas. Isolates SH2, SHA2 and SHD5 were suspected as Pseudomonas, while SHB1 as Erwinia.

The main differences in the character of the genus Pseudomonas, Erwinia and Xanthomonas are the color of the colony which indicates the presence of xanthomonadin pigments, oxygen requirement, nitrates reduction, and the production of cytochrome oxidase enzymes. Xanthomonas is an aerobic obligate bacterium with a bacterial colony when isolated must be yellow because it contains xanthomonadin, a negative oxidase, and is unable to reduce nitrates to nitrites [11].

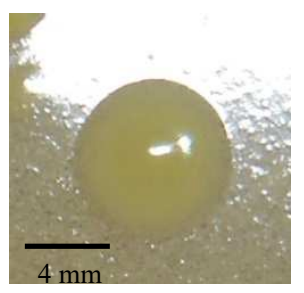

a.

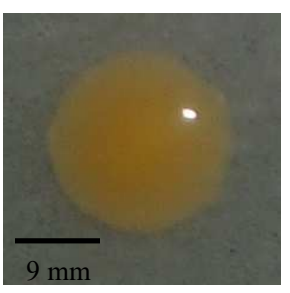

b.

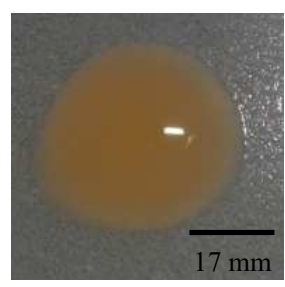

c.

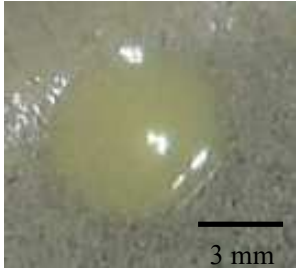

d.

Figure 2. The morphology and size of selected isolate colonies capable of producing biogum from alternative carbon sources: a) SH2, b) SHA2, c) SHB1, d) SHD5. The four isolates showed the characteristics of a colony with a smooth and shiny surface (mucoid). Isolates SH2 and SHD5 had yellow, while isolates SHA2 and SHB1 have an orange colony.

Pseudomonas and Erwinia infections in Brassicaceae family plants are usually found in parts of plants that have been injured. In addition, some Pseudomonas species such as Pseudomonas fluorescens are able to produce viscous chemicals that can penetrate highly waxy surface structures such as broccoli florets, causing other bacteria to participate in infected plants. The characteristics of leaves infected with Erwinia and Pseudomonas have similarities to leaves infected by Xanthomonas (Koike et al., 2007). Therefore, although the selected leaves have symptoms of black rot, there is a high possibility that the isolated bacteria were Pseudomonas and Erwinia. 
Table 1. The phenotypic character of four bacteria producing biogum from an alternative source of carbon cassava bagasse

\begin{tabular}{|c|c|c|c|c|}
\hline \multirow{2}{*}{ Characters tested } & \multicolumn{4}{|c|}{ Isolates } \\
\hline & SH 2 & SHA 2 & SHB 1 & SHD 5 \\
\hline \multicolumn{5}{|l|}{ Morphology of colony } \\
\hline 1. Form & Circular & Circular & Circular & Circular \\
\hline 2. Colour & Yellow & Orange & Orange & Yellow pale \\
\hline 3. Margin & Entire & Entire & Entire & Entire \\
\hline 4. Elevation & Convex & Convex & Convex & Convex \\
\hline 5. Internal & Opaque & Opaque & Opaque & Opaque \\
\hline 6. Surface & Mucoid & Mucoid & Mucoid & Mucoid \\
\hline \multicolumn{5}{|l|}{ Morphology of cell } \\
\hline 1. Form & Bacil & Bacil & Bacil & Bacil \\
\hline 2. Arrangement & Single & Single & Single & Single \\
\hline 3. Gram reaction & - & - & - & - \\
\hline 4. Endosprorestaining & - & - & - & - \\
\hline 5. Capsule staining & + & + & + & + \\
\hline 6. Acid staining & - & - & - & - \\
\hline 7. Motility & - & - & + & - \\
\hline 8. $\mathrm{KOH} 10 \%$ test & - & - & - & - \\
\hline \multicolumn{5}{|l|}{ Biochemistry tests } \\
\hline 1. Catalase & + & + & + & + \\
\hline 2. $\mathrm{H}_{2} \mathrm{~S}$ production & - & - & - & - \\
\hline 3. Hydrolisis of starch & - & - & - & - \\
\hline 4. Hydrolysis of casein & + & + & - & - \\
\hline 5. Hydrolysis gelatin & - & - & - & - \\
\hline 6. Indol formation & - & - & - & - \\
\hline 7. Nitrat reduction & - & - & - & + \\
\hline 8. Cytochrom oxidase & + & + & - & + \\
\hline 9. Urease & - & - & - & + \\
\hline 10. Methyl red (MRVP) & - & - & - & + \\
\hline 11. Voges-Proskauer (MRVP) & - & - & - & - \\
\hline \multicolumn{5}{|l|}{ 12. Gas production of: } \\
\hline a. Glucose & - & + & - & + \\
\hline b. Fructose & - & - & - & + \\
\hline c. Sucrose & - & - & - & + \\
\hline d. Maltose & - & + & - & - \\
\hline e. Lactose & + & + & + & + \\
\hline f. Mannitol & - & - & - & - \\
\hline
\end{tabular}


Table 1. (Continued)

\begin{tabular}{|c|c|c|c|c|}
\hline \multirow{2}{*}{ Characters tested } & \multicolumn{4}{|c|}{ Isolates } \\
\hline & SH 2 & SHA 2 & SHB 1 & SHD 5 \\
\hline \multicolumn{5}{|l|}{ Physiological characters } \\
\hline \multicolumn{5}{|l|}{ 1. Growth in $\mathrm{pH}$ : } \\
\hline$-3,5$ & - & - & - & - \\
\hline-5 & + & + & - & + \\
\hline$-6,5$ & + & + & + & + \\
\hline-9 & + & + & + & + \\
\hline-12 & - & - & - & - \\
\hline \multicolumn{5}{|l|}{ 2. Growth in suhu: } \\
\hline$-4^{\circ} \mathrm{C}$ & + & + & + & + \\
\hline$-35^{\circ} \mathrm{C}$ & + & + & + & + \\
\hline$-45^{\circ} \mathrm{C}$ & + & - & - & - \\
\hline \multicolumn{5}{|l|}{ 3. Growth in $\mathrm{NaCl}$ : } \\
\hline$-\mathrm{NaCl} 0,5 \%$ & + & + & + & + \\
\hline$-\mathrm{NaCl} 1 \%$ & + & + & + & + \\
\hline$-\mathrm{NaCl} 3 \%$ & + & + & + & + \\
\hline$-\mathrm{NaCl} 5 \%$ & + & + & + & + \\
\hline 4. Oxygen requirement & $\begin{array}{l}\text { Anaerob } \\
\text { facultative }\end{array}$ & $\begin{array}{l}\text { Anaerob } \\
\text { facultative }\end{array}$ & $\begin{array}{l}\text { Anaerob } \\
\text { facultative }\end{array}$ & $\begin{array}{l}\text { Anaerob } \\
\text { facultative }\end{array}$ \\
\hline \multicolumn{5}{|l|}{ Reaction to antibiotics } \\
\hline 1. Chloramphenicol & Sensitive & Sensitive & Sensitive & Sensitive \\
\hline 2. Ampicilin & Sensitive & Sensitive & Sensitive & Sensitive \\
\hline 3. Tetracycline & Sensitive & Sensitive & Sensitive & Sensitive \\
\hline
\end{tabular}




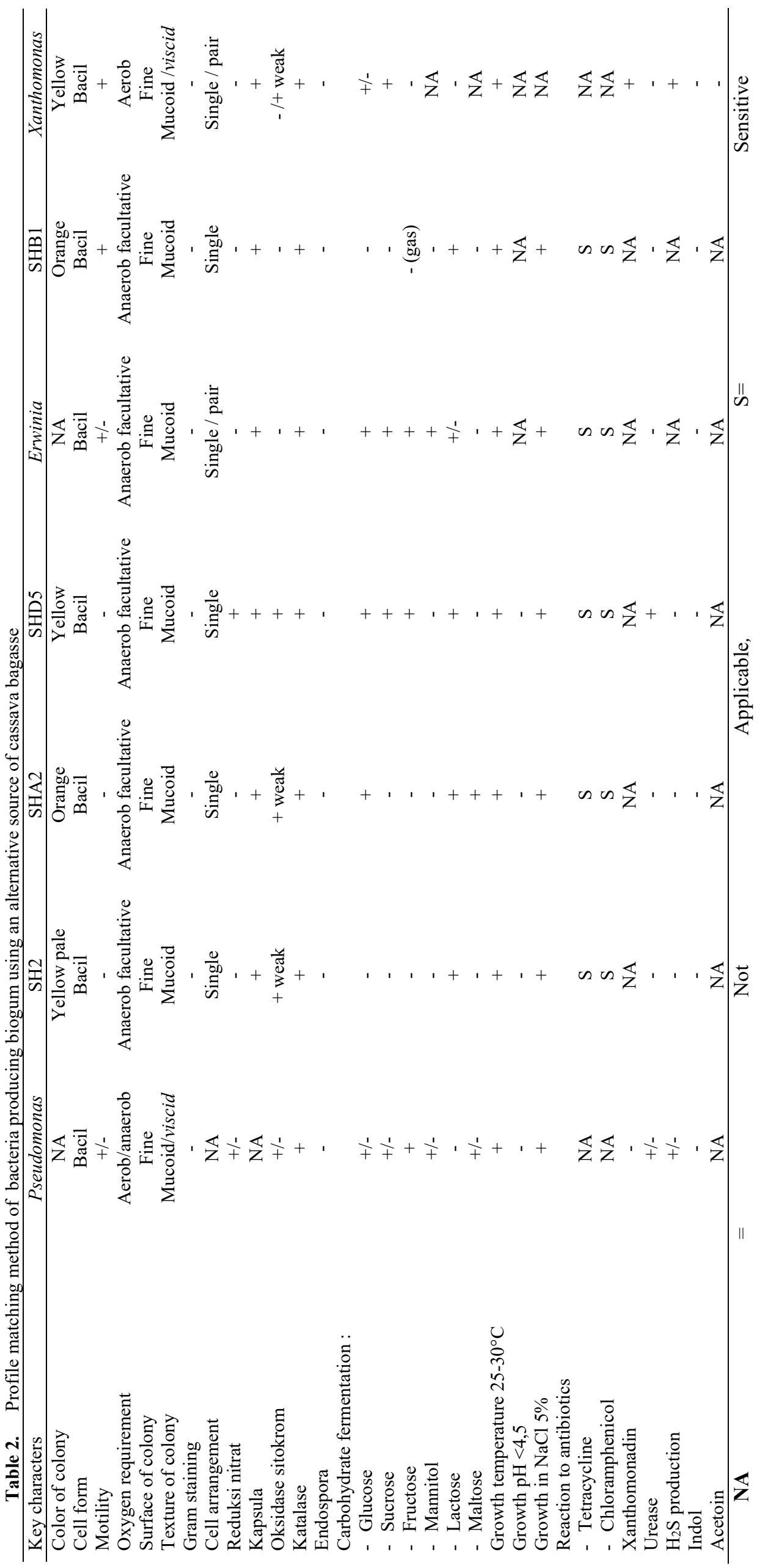




\section{Conclusion}

Ten bacteria were isolated from green mustard leaves with black rot symptoms in Kopeng, Magelang, Central Java, and they were SH2, SHA1, SHA2, SHA3, SHB1, SHB3, SHC1, SHD2, SHD5, and SHE. All bacterial isolates were able to produce bio gum using growth media and fermentation media with carbon sources of cassava bagasse. However, there are 4 selected isolates and they are SH2, SHA2, SHB1, and SHD5 which have high biogum production. The four biogum-producing isolates were identified as Pseudomonas ( $\mathrm{SH}$, SHA2, SHD5) and Erwinia (SHB1).

\section{Reference}

[1] J. Plank, S. Ng, and S. Foraita, "Intercalation of the microbial biopolymers welan gum and EPS I into layered double hydroxides," Zeitschrift fur Naturforsch. - Sect. B J. Chem. Sci., vol. 67, no. 5, pp. 479-487, 2012, doi: 10.5560/ZNB.2012-0081.

[2] B. de M. Lopes, V. L. Lessa, B. M. Silva, M. A. da S. C. Filho, E. Schnitzler, and L. G. Lacerda, "Xanthan gum: Properties, production conditions, quality and economic perspective," J. Food Nutr. Res., vol. 54, no. 3, pp. 185-194, 2015.

[3] J. Cruz, R. Tenreiro, and L. Cruz, "Assessment of diversity of Xanthomonas campestris pathovars affecting cruciferous plants in Portugal and disclosure of two novel X. campestris pv. campestris races," J. Plant Pathol., vol. 99, no. 2, pp. $403-$ 414, 2017, doi: 10.4454/JPP.V99I2.3890.

[4] S. Rosalam and R. England, "Review of xanthan gum production from unmodified starches by Xanthomonas comprestris sp.," Enzyme Microb. Technol., vol. 39, no. 2, pp. 197-207, 2006, doi: 10.1016/j.enzmictec.2005.10.019.

[5] A. V Gomashe, P. G. Dharmik, and P. S. Fuke, "Optimization And Production Of Xanthan Gum By Xanthomonas Campestris NRRL-B-1449 From Sugar Beet Molasses," Int. J. Eng. Sci., vol. 2, no. 5, pp. 52-55, 2013.

[6] Z. Fang, Pretreatment Techniques for Biofuels and Biorefineries, vol. 115. 2013.

[7] Q. Li, "Xanthan gum production by Xanthomonas campestris pv. campestris 8004 using cassava starch as carbon source," African J. Biotechnol., vol. 11, no. 73, pp. 13809-13813, 2012, doi: 10.5897/ajb11.3774.

[8] B. Hidayat, U. Hasanudin, S. Nurjanah, and N. Yuliana, "Improvement of cassava bagasse flour characteristics to increase their potential use as food," in IOP Conference Series: Earth and Environmental Science, 2018, vol. 209, no. 1, doi: 10.1088/1755-1315/209/1/012006.

[9] R. Jabeen, T. Iftikhar, and H. Batool, "Isolation, characterization, preservation and pathogenicity test of Xanthomonas Oryzae PV. Oryzae causing BLB disease in Rice," Pakistan J. Bot., vol. 44, no. 1, pp. 261-265, 2012.

[10] N. Amenaghawon, S. Osemwengie, O. Omoregbe, and U. Asogwa, "Application of Experimental Design Method for the Optimisation of Xanthan Gum Production from Pineapple Peels Using Xanthomonas Campestris via Submerged Fermentation," Niger. J. Technol., vol. 34, no. 3, p. 491, 2015, doi: 10.4314/njt.v34i3.10.

[11] T. A. Schöner, S. W. Fuchs, B. Reinhold-Hurek, and H. B. Bode, "Identification and biosynthesis of a novel xanthomonadin-dialkylresorcinol- hybrid from Azoarcus sp. BH72," PLoS One, vol. 9, no. 3, 2014, doi: 10.1371/journal.pone.0090922. 
